\title{
PRIMATE SELFIES AND ANTHROPOZOONOTIC DISEASES: \\ LACK OF RULE COMPLIANCE AND POOR RISK PERCEPTION THREATENS \\ ORANGUTANS
}

\author{
Andrea Molyneaux ${ }^{\mathrm{a}, \mathrm{b}}$ Emma Hankinson ${ }^{\mathrm{c}}$, Mbra Kabana, Magdalena S. Svensson ${ }^{\mathrm{c}}$ \\ Susan M. Cheyne ${ }^{c, d}$ Vincent Nijman $^{b, c}$ \\ ${ }^{a}$ Green Hill, Bukit Lawang, North Sumatra, Indonesia \\ ${ }^{b}$ Oxford Wildlife Trade Research Group, Oxford Brookes, University, Oxford, UK \\ ${ }^{c}$ School of Social Sciences, Oxford Brookes University, Oxford, UK \\ ${ }^{d}$ Borneo Nature Foundation, Palangka Raya, Indonesia
}

Keywords: Compliance $\cdot$ Disease transmission $\cdot$ Ecotourism $\cdot$ Great apes $\cdot$ Sumatran orangutan

\begin{abstract}
Our understanding of the transmission of anthropozoonotic diseases between humans and non-human primates, particularly great apes due to their close genetic relationship with humans, highlights a serious potential threat to the survival of these species. This is particularly the case at tourism sites where risk of disease transmission is increased. We focus on the interaction between tourists and the Critically Endangered Sumatran orangutan (Pongo abelii) at Bukit Lawang in the Gunung Leuser National Park, Indonesia, before and after the park was closed due to the threat of COVID-19 in April 2020. Through analysis of posts on Instagram we determine the extent of compliance by visitors with the rule to keep a minimum distance of $10 \mathrm{~m}$ from orangutans and assess the positional behaviours of the orangutans. Of the 2,229 photographs we assessed between November 2019 and July 2020, 279 depicted one or more orangutans. Forty-two of these contained both a human and an orangutan, and of these all showed inappropriate behaviours (direct contact, feeding orangutans, close proximity $<5 \mathrm{~m}$ ) providing direct evidence of non-compliance with the 10-m distance rule. Most of these photographs additionally showed orangutans performing abnormal positional behaviours such as being low to or on the ground rather than their natural high position in the canopy; being near the ground and in close proximity to humans increases the risk of anthropozoonotic disease transmission. As expected, we found a
\end{abstract}


significant decrease in number of photographs that were posted following the closure, and a decrease in the proportion of photographs that showed orangutans, or tourists feeding orangutans. Tourists do not seem to perceive that they pose risks to the orangutans and therefore increased awareness, education and enforcement of rules by all stakeholders, tourism bodies and government officials need to be actioned in order to safeguard this important population, which is crucial to the future survival of the Sumatran orangutan.

\section{INTRODUCTION}

Many pathogenic diseases affecting humans are zoonotic [Morse et al., 2012], and non-human primates are similarly susceptible to human pathogens [Buitendijk et al., 2014; Dunay et al., 2018; Patrono et al., 2018; Gillespie and Leendertz, 2020]. Many diseases impacting non-human primates are likely of human origin and include intestinal viruses (polio, hepatitis, herpes), bacteria (Campylobacter spp., Salmonella spp.), parasites (Giardia lamblia, Schistosoma spp.) and respiratory viruses (measles, influenza) and bacteria (Streptococcus pneumoniae, Mycobacterium tuberculosis) [Devaux et al., 2019]. Owing to their close genetic proximity to humans, great apes are of particular concern in regard to disease transmission. Previous disease outbreaks have devastated populations and have had major impacts on great ape conservation, such as the Ebola outbreak in central Africa, which was responsible for the death of $95 \%$ of western lowland gorillas (Gorilla gorilla gorilla) between 2002 and 2004 [Genton et al., 2012].

Respiratory infections, such as pneumonia, tuberculosis and influenza, are a serious threat to great apes [Köndgen et al., 2008; Buitendijk et al., 2014; Emery Thompson et al., 2018; Patrono et al., 2018; Scully et al., 2018; Glasser et al., 2021]. For example, an outbreak between 2016 and 2017 of a respiratory illness in wild chimpanzees (Pan troglodytes) was caused by the OC43 human coronavirus [Patrono et al., 2018]. A review of pathogens transmitted from humans to great apes revealed 33 records of which the majority related to respiratory illness in semi-wild populations of chimpanzees and gorillas, and only 2 recorded cases related to orangutans (Pongo spp.) [Dunay et al., 2018]. It is thought that the lack of recorded mass mortality events from infectious disease in orangutans could be due to their more solitary nature in comparison to the African great apes [Philippa and Dench, 2019]. However, 
orangutans, especially wild populations, are underrepresented in the literature on great apes and infectious diseases [Mul et al., 2007; Nurcahyo et al., 2017; Philippa and Dench, 2019; Stuart et al., 2020], and the majority of these data is from captive populations in zoos, sanctuaries and rehabilitation centres.

A 2019 review examining the prevalence of infectious diseases in orangutans (wild and captive) revealed 96 infectious diseases with the majority of these accounts sourced from only 7 studies [Wells et al., 1990; Kalter et al., 1997; Warren, 2001; Kilbourn et al., 2003; Mul et al., 2007; Foitová et al., 2009; Labes et al., 2010]. While hepatitis B and tuberculosis were thought to have significant potential for cross-species transmission due to their prevalence in the human populations of orangutan home range countries, respiratory diseases were again the primary infectious diseases of concern. Enteric bacteria, often detected in cases of respiratory disease (causing air sacculitis from inhalation of faecal contaminants) could also be a source of infection. The susceptibility of great apes to human pathogens needs to be managed appropriately [Philippa and Dench, 2019].

Additionally, 51 parasite species are known to infect orangutans [Nurcahyo et al., 2017]. Semiwild and captive orangutans are more frequently infected by Cryptosporidium sp. than wild orangutans [Mynářová et al., 2016], and 76\% of samples from semi-wild Sumatran orangutans (Pongo abelii) in Bukit Lawang, north Sumatra, tested positive for Entamoeba [Stuart et al., 2020]. More recently, concerns have been raised by a plethora of scientists regarding the COVID-19 pandemic, its impacts on biodiversity conservation and specifically its impact on non-human primate species [Corlett et al., 2020; Santos et al., 2020]. A recent study has shown that all great apes and all African and Asian monkeys are potentially susceptible to SARS-CoV-2 infection [Melin et al., 2020]. In January 2021 three captive western lowland gorillas in San Diego Zoo were confirmed positive for SARS-CoV-2 (they have since recovered and received an experimental COVID-19 vaccine [USDA, 2021]). In September 2021, 18 out of the 20 western gorillas at Atlanta Zoo were reported to be symptomatic for COVID-19 with 9 testing positive for SARS-CoV-2 [Zoo Atlanta, 2021].

Increased contact with humans has long been highlighted as a significant risk factor that exposes orangutans to infectious diseases [Köndgen et al., 2008; Dellatore et al., 2009; Foitová et al., 2009; Muehlenbein et al., 2010; Kuze et al., 2012; Mynářová et al., 2016; Russon et al., 2016; Nurcahyo 
et al., 2017; Dunay et al., 2018; Stuart et al., 2020]. Orangutans' susceptibility to infectious diseases can be exacerbated by numerous stress factors which negatively impact their welfare such as altered behaviours (more time on ground) and habituation (close human contact) [Muehlenbein et al., 2010; Moorhouse et al., 2015]. The human-primate interface afforded by tourism is particularly problematic [Lappan et al., 2020], and it is suggested that the risk posed by tourists to great apes increases as the distance between the two decreases [Van Hamme et al., 2021].

In order to mitigate the risks presented by human visitors, the need for visitor education has been emphasized [Muehlenbein and Wallis, 2014]. Conservationists have strongly urged the use and implementation of best practice guidelines on great ape tourism and health monitoring [Macfie and Williamson, 2010; Gilardi et al., 2015; Dunay et al., 2018; Gillespie and Leendertz, 2020]. However, actual implementation of these guidelines has been inconsistent [Dunay et al., 2018; Hanes et al., 2018; Otsuka and Yamakoshi, 2020], and there appears to be much non-compliance [Weber et al., 2020; Glasser et al., 2021; Van Hamme et al., 2021]. Compliance with rules and regulations receives little attention in conservation literature despite its underpinning much of nature conservation [Keane et al., 2008; Arias, 2015; Solomon et al., 2015; Fairbrass et al., 2016]. In order to undertake impactful research with effective outcomes, the nature of non-compliance needs to be understood. Examining noncompliance from a risk perception and risk communication perspective can provide valuable insights [Decker et al., 2010; Fairbrass et al., 2016; Abrams et al., 2020].

The International Union for Conservation of Nature (IUCN) advise (in addition to other measures) maintaining a distance of $10 \mathrm{~m}$ from great apes at all times [IUCN, 2020], and the majority of great ape tourism sites closed to all visitors (both tourists and researchers) by the end of March 2020 in response to the COVID-19 pandemic. Many statements targeting the threats of COVID-19 focused on African great apes [Carrington, 2020; Lewis, 2020; UN, 2020; UNESCO, 2020]. There are few reports regarding the impact on or the action taken by the many sites in Indonesia involving orangutan tourism, research or rehabilitation [Karokaro and Jong, 2020; Montague, 2020; SOCP, 2020; Vyawahare, 2020]. To safeguard the orangutan population and to reduce the risk of transmission in north Sumatra, the local governmental authorities acted decisively by closing the Gunung Leuser National Park, the Sumatran orangutans' stronghold, to all visitors on March 18, 2020, and in Bukit 
Lawang by distributing a detailed information leaflet to all guest houses and the local tourist guide association.

Social media offers a novel and convenient method for investigating compliance and other issues, such as welfare, at great ape tourism sites [Nekaris et al., 2016; Van Hamme et al., 2021]. Here we review posts on the social media platform Instagram and use this information to assess risk perceptions and the risk of disease transmission from visitors to the orangutan population in Bukit Lawang, the main site within Gunung Leuser National Park where tourists come to observe orangutans. Based on published research, personal observations of tourist behaviours and preliminary reviews of social media we hypothesize that (1) non-compliance with the 10-m distance rule will occur (H1), (2) national park closure will be effective in reducing the risk of disease transmission (H2), (3) orangutans will demonstrate habituation and exhibit unnatural positional behaviours (H3) and (4) visitors' perception of risk to both themselves and the orangutans will be low (H4).

\section{MATERIAL AND METHODS}

\section{Study area}

Bukit Lawang is a tourist-focused village located within the Langkat district of north Sumatra $\left(03^{\circ} 32.770^{\prime} \mathrm{N}, 098^{\circ} 07.000^{\prime} \mathrm{E}\right)$ on the eastern edge of the Gunung Leuser National Park, adjacent to the Bohorok river. Bukit Lawang has a long affiliation with orangutan tourism (dating back to the early 1970s) as well as its associated problems such as lack of rule compliance and decreased orangutan welfare [Rijksen and Meijaard, 1999; Dellatore et al., 2009; Kuze et al., 2012; Dellatore et al., 2014; Susilawati et al., 2020]. In 1973, an orangutan rehabilitation centre was opened in Bukit Lawang. Over time a growing body of evidence revealed that close contact with humans was dangerous for orangutans, and also the release of rehabilitated orangutans posed a risk to wild populations, and therefore the centre was closed in 1991 [Smits et al., 1995; Russon et al., 2001]. However, official supplementary feedings by national park rangers to the now released, semi-wild orangutans and illegal feedings by guides and guests during jungle treks perpetuated the problems associated with close contact. Although the feeding platform and viewing sessions were discontinued in 2015 , there is still a large tourism industry focusing on activities in the national park. Feeding and close contact still persist despite rules and guidelines 
issued by the national park authorities regarding wildlife viewing and safety information and Indonesian law (UU No. 5 tahun 1990; Conservation of living Natural Resources and Ecosystem; article 21, paragraph 2) which prohibits injury to protected animals (feeding and getting close to orangutans can damage their health and comes under the definition of injury). Beginning in early 2018, the national park authority has worked together with local scientists to produce detailed educational information on the rules associated with orangutan viewing, anthropozoonotic risks and practical applications to disseminate this information.

\section{Data collection}

Starting in April 2020 we systematically searched for photographs shared publicly on the popular photo sharing app Instagram, using \#bukitlawang. Photographs were retrieved retrospectively based on the dates they were posted. As the national park was closed on March 18, 2020, and reopened for Indonesian visitors in August 2020, we retrieved photographs from 5 months prior to the official closure of the national park (November 2019 to March 2020) and 4 months following closure (April to July 2020). We sampled a randomly selected, consecutive 10-day period each month and recorded the total number of photographs posted with \#bukitlawang. From these photographs, we selected all photographs containing an orangutan and removed all others containing the village, markets, restaurants, food, landscapes, people etc. In order to investigate the impact of closing the national park, photos that were posted after closure but actually taken prior to closure (as evidenced by comments or dates) were excluded. Photos that were posted after closure but had no information to accurately date them to have been taken prior to closure were included in our analysis. We categorized photographs into: (1) both a human and orangutan present within the photograph at close proximity $(<5 \mathrm{~m})$ and (2) photographs of an orangutan without a human present but indicating close proximity $(<5 \mathrm{~m})$. Close proximity was implied by the position of the human present in the photograph, or where photographs were taken extremely close (when it was evident that a zoom lens had not been used) and could not have been obtained without breaking the rule to keep a minimum distance of $10 \mathrm{~m}$. To determine whether or not a zoom lens was used we examined the style and quality of the photograph, the position and behaviour of the orangutan, and the account profile and history. To investigate orangutan positional behaviours, 
habituation and visitors' perception of the risks, photographs containing both a human and an orangutan were analysed in terms of: (1) estimated distance between the orangutan and human showing direct contact (touching/feeding) or close proximity $(<5 \mathrm{~m}),(2)$ the position of the orangutan within the forest canopy, on the ground, within a small tree or sapling $<3 \mathrm{~m}$ in height, and $>3 \mathrm{~m}$ high in the canopy, (3) the sex and age of all orangutans present in close or direct contact with humans (to assess the risk perception of visitors to this species in relation to age and sex).

\section{Statistical Analysis}

We used $t$ tests for two independent means to compare the monthly number of photographs posted prior to and following closure of the national park, to compare monthly number and percentage of photographs posted containing orangutans, and monthly number and percentage of photographs showing close proximity (i.e., estimated at $<5 \mathrm{~m}$ ) or direct contact of orangutans and humans before and following national park closure. Prior to analysis we checked whether or not the data approached a normal distribution, and we checked for homogeneity of variance. We present means $\pm \mathrm{SD}$. We carried out all tests using SPSS v.26, and we accept significance when $\mathrm{p}<0.05$ in a two-tailed test

\section{RESULTS}

Within the 8-month period of data collection, 2,167 photographs were obtained under the hashtag \#bukitlawang, including 1,389 before and 778 after national park closure (Table 1). There was a decrease in the total number of photographs posted in the 4 months after the closure of the national park ( $278 \pm 66$ before vs. $194 \pm 60$ per month after, $\mathrm{t}=1.964, \mathrm{p}=0.090)$, and the number of photographs containing orangutans significantly decreased ( $50 \pm 6$ before vs. $7 \pm 2$ per month after, $t$ $=13.47, \mathrm{p}<0.001)$. There was a significant difference in the number of photographs including an orangutan before and after national park closure $(\mathrm{t}=6.415, \mathrm{p}<0.001)$ in terms of the percentage of photographs that included an orangutan $(18 \pm 4 \%$ before and $4 \pm 2 \%$ after $)$. 


\begin{tabular}{|c|c|c|c|c|c|}
\hline & \multicolumn{3}{|c|}{ Number of photographs } & \multicolumn{2}{|c|}{ Photos of orangutan and human } \\
\hline & \#bukitlawang & including orangutan & $\begin{array}{l}\text { including orangutan } \\
\text { and human }<5 \mathrm{~m} \text { or } \\
\text { direct contact }\end{array}$ & $\begin{array}{l}\text { orangutan } \\
\text { on ground }\end{array}$ & $\begin{array}{l}\text { orangutan in small } \\
\text { tree }<3 \mathrm{~m} \text { high }\end{array}$ \\
\hline November & 225 & 46 & 7 & 4 & 3 \\
\hline December & 300 & 45 & 7 & 1 & 4 \\
\hline January & 378 & 59 & 7 & 3 & 4 \\
\hline February & 216 & 53 & 9 & 2 & 7 \\
\hline \multirow[t]{2}{*}{ March } & 270 & 47 & 10 & 4 & 6 \\
\hline & \multicolumn{5}{|c|}{ National park is closed } \\
\hline April & 146 & 9 & 1 & 1 & 0 \\
\hline May & 144 & 9 & 0 & 0 & 0 \\
\hline June & 266 & 7 & 0 & 0 & 0 \\
\hline \multirow[t]{2}{*}{ July } & 222 & 4 & 1 & 1 & 0 \\
\hline & $\begin{array}{l}\text { Mean } \pm S D \text { (total) } \\
\text { range per month }\end{array}$ & $\begin{array}{l}\text { Mean } \pm \mathrm{SD} \text { (total) rang } \\
\text { in percentage }\end{array}$ & $\begin{array}{l}\text { Mean } \pm \text { SD (total) } \\
\text { range in percentage }\end{array}$ & Mean \pm SD (total) & Mean $\pm S D$ (total) \\
\hline \multirow[t]{2}{*}{ Before closure } & $277.8 \pm 65.6(1,389)$ & $50.0 \pm 5.9(250)$ & $8.0 \pm 1.4(40)$ & $2.8 \pm 1.3(14)$ & $4.8 \pm 1.6(24)$ \\
\hline & $216-378$ & $15-25$ & $12-21$ & & \\
\hline \multirow[t]{2}{*}{ After closure } & $194.5 \pm 59.9(778)$ & $7.3 \pm 2.4(29)$ & $0.5 \pm 0.6(2)$ & $0.5 \pm 0.6(2)$ & $0(0)$ \\
\hline & $144-266$ & $2-6$ & $0-25$ & & \\
\hline
\end{tabular}

We observed a significant decrease in the percentage of photographs showing both an orangutan and a human in close proximity $(<5 \mathrm{~m})$ or in direct contact (including the feeding of the orangutan) following closure. Prior to the closure $16 \pm 3 \%$ of these photographs show close contact whereas afterwards this decreased to $3 \pm 5 \%(t=6.652, p<0.001)$. In photographs showing both an orangutan and a human, $60 \%$ of orangutans were single adult females, $20 \%$ were adult females with offspring, $13 \%$ were juveniles of either sex, and $8 \%$ were of fully developed adult males (possessing cheek flanges).

Additionally, the number of photographs containing orangutans that indicated close proximity $(<5 \mathrm{~m})$ of a human - but no human was present in the photograph - decreased after closure of the national park from 108 out of 250 to 6 out of 29.

The behaviour of the orangutans when in close proximity to humans, as expressed through their position in the forest canopy (using aggregate data for the total collection period) revealed 14 instances on the ground, 24 in a small tree or sapling $<3 \mathrm{~m}$ in height, and 2 in a tree $>3 \mathrm{~m}$ high in the canopy. In relation to human behaviour towards orangutans, analysis revealed 5 instances of feeding, 3 directly touching, and 34 in close proximity $<5 \mathrm{~m}$ of an orangutan. 


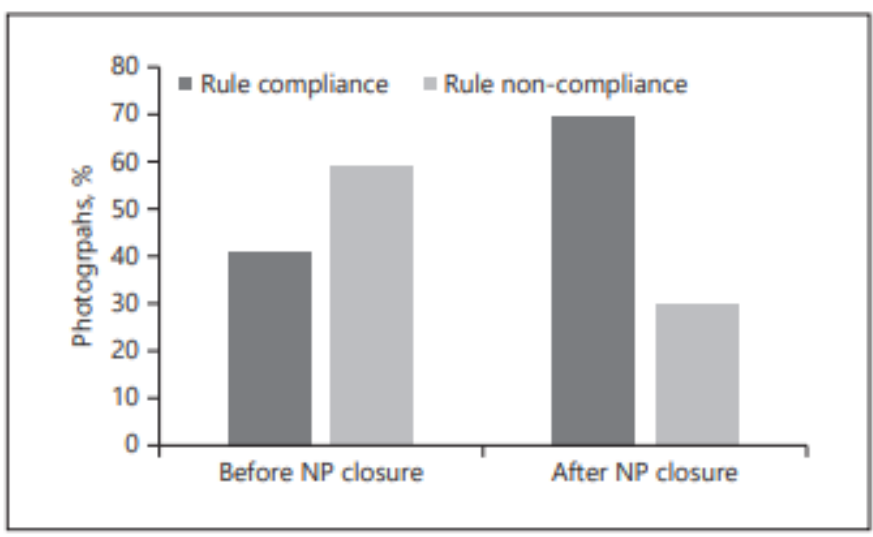

Fig. 1. Percentage of photographs including an orangutan reflecting compliance and non-compliance of national park (NP) rules (non-compliance: before NP closure $n=148 / 250$; after NP closure $n=8 / 29$ ). Non-compliance includes: $<5 \mathrm{~m}$ distance, direct contact or feeding of orangutans by visitors. Compliance reflects: no photographic evidence of rule breaking in relation to photographs taken of orangutans and orangutans and humans.

\section{DISCUSSION}

We show here, using photographs posted on Instagram by tourists, that it is possible to study compliance and to assess potential risks of transmission of anthropozoonotic diseases between humans and nonhuman primates. Directly studying non-compliance with rules presents challenges as participants may be reluctant to participate and speak freely, and data are often collected after interventions, limiting its quality [Keane et al., 2008]. Using social media offers an opportunity to generate data without such constraints and can be a cost efficient and complementary data source for conservation research [Wilkins et al., 2020]. However, associated biases and ethical issues that are inherent to online data collection must be carefully considered, and therefore caution should be exercised when interpreting our findings [Toivenan et al., 2019]. For instance, the data collected for this study provides us with information about what is posted on Instagram but this may not be representative of actual numbers of visitors or the behaviours of all visitors to the national park.

In the time periods assessed, all 42 photographs containing both an orangutan and a human, and 114 photographs of just an orangutan (no human present) illustrated non-compliance with the 10-m distance rule, and thus show that there is a risk of disease transmission (Fig. 1). The human behaviours illustrated are inappropriate, against the rules and guidelines, and clearly demonstrate non-compliance, supporting our first hypothesis that non-compliance with the distance rule would occur (Fig. 2). Photographs 
showing direct contact or close proximity $<5 \mathrm{~m}$ also indicate a high level of habituation of the resident orangutans to the presence of humans, supporting our third hypothesis that orangutans will demonstrate habituation. In $95 \%$ of these photographs, orangutans were seen either on the ground or within a small tree sapling at a height of $<3 \mathrm{~m}$. Although Bornean orangutans (P. pygmaeus) have been documented to show terrestrial behaviour [Ancrenaz et al., 2014], it is extremely rare to see a wild Sumatran orangutan on the ground; our results thus indicate an alteration to natural behaviours, likely to exacerbate susceptibility to any disease risk, further supporting our third hypothesis that orangutans will exhibit unnatural positional behaviours [Delgado and van Schaik, 2000; Dellatore et al., 2014].

There was a significant decrease in the percentage of photographs showing orangutans and humans in close proximity or in direct contact after national park closure. This indicates that the closure of the park was effective in reducing the amount of contact between humans and orangutans, including the risk of the new threat of COVID-19 and other potential disease transmission. This supports our second hypothesis that national park closure will be effective in reducing the risk of disease transmission.

The COVID-19 pandemic has increased people's awareness of zoonoses and potentially heightened risk perception, and this may have positive impacts on the behaviour of visitors to the Gunung Leuser National Park, making them more likely to comply with the rules [Lappan et al., 2020]. This is urgently needed, because while closing the national park dramatically lowers the risk of disease transmission, permanent closure to human visitors is unrealistic and zero impact tourism simply does not exist. If the benefits of the park's closure are to be capitalized on and these benefits made more long term, then changes must be made to the way visitors behave during jungle trekking activities, the information provided to inform people of the risks needs to be supported and awareness of it promoted by all stakeholders [Lappan et al., 2020].

Frequent close proximity and direct contact between visitors to Bukit Lawang and the orangutans (all sexes and ages) suggests that visitors perceive little or no risk associated with their behaviour supporting our fourth hypothesis that visitors' risk perceptions will be low. Female adult orangutans are present in $60 \%$ of photographs, and therefore they may have developed a lowered perception of the risk from humans, whereas female orangutans with offspring are perhaps more risk 
averse and stay away from humans ( $20 \%$ of photographs). Research into photographs with gorillas has shown that tourists tend to get closer to young gorillas, perhaps reflecting that those tourists see them as less of a risk than their adult counterparts and that infants have a lower risk perception of humans [Van Hamme et al., 2021]. However, our data should be interpreted with caution, as it is possible that some females had infants who did not appear in the photos. The juveniles' mothers may have been nearby and similarly did not appear in the photos. The fact that only 3 photographs show a fully developed adult male could be explained by orangutan social structure, which means that there are fewer adult males in the area and they are less habituated to human visitors. It could also be that people are more aware of the risks of getting close to a physically large and fully developed adult male orangutan.
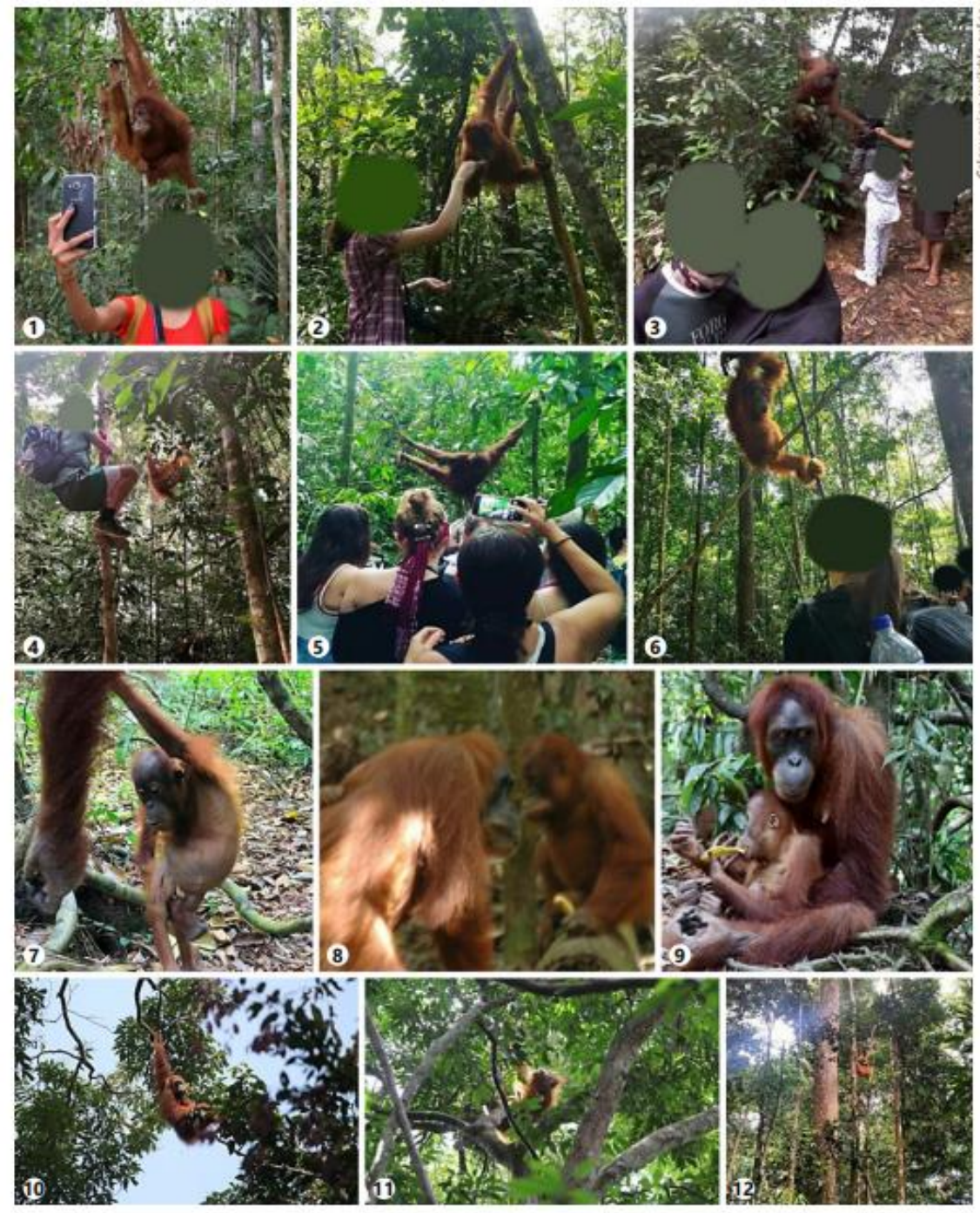

Fig. 2. Photographs obtained from Instagram illustrating non-compliance (human present 1-6, not present 7-9) and compliance (10-12) with national park rules by visitors to Bukit Lawang, North Sumatra. 
It is an interesting paradox that human visitors often express concern for the welfare and survival of orangutans, evidenced by comments on the Instagram photographs, yet they do not perceive that their own actions, of getting close for a selfie, present a risk and compromise the health of the very orangutans they are viewing [Muehlenbein et al., 2008]. Our study indicates a gap in knowledge about orangutans. Provision of information can remove knowledge barriers, increase awareness and influence compliance [Arias, 2015]. In order to address and understand this apparent gap in knowledge and develop and implement effective risk communication information, we need to try and consider why the available rules are not complied with [Arias, 2015; Solomon et al., 2015; Fairbrass et al., 2016] and how risks are perceived [Decker et al., 2010; Hanisch-Kirkbride et al., 2013].

Three factors that influence risk perception are: (1) community culture, (2) societal risk response and (3) characteristics of the risk itself. Societal risk response constitutes the quality and quantity of media coverage and the actions of risk management agencies and education efforts of official bodies [Decker et al., 2010]. Media is riddled with images showing close contact with animals and wildlife. Often such images are of celebrities, TV presenters and researchers. Such imagery normalizes close contact, exacerbates any lack of societal risk response and diminishes the perception that human behaviours can cause risk [Van der Meer et al., 2019; Lenzi et al., 2020; Thomas-Walters et al., 2020]. It has been suggested that primatologists should lead the way by promoting and following safe practices including not being photographed holding primates or using and sharing photos showing close humanprimate spacing [Lappan et al., 2020]. In looking at the characteristics of a risk itself and how it influences risk perception, the only aspects of a risk that are important are those that people are aware of and that perceived characteristics of a risk precede their response [Decker et al., 2010].

There are whole agencies, government departments and many experts who specialize in dealing with risk communication, particularly in response to the COVID-19 pandemic. Conservation as a discipline needs to work across different fields (e.g., psychology, sociology, criminology, economics, risk and decision science) to engage with and learn from such experts [Dick et al., 2017], rather than expecting researchers to be able to communicate effectively without any specific training or consideration of this aspect [Rizzolo, 2017]. This issue is multifactorial; rules and guidelines are pointless without compliance which cannot be taken for granted. Enforcement is not as simple as just 
expecting compliance. Conservation outcomes can be improved by embracing techniques from different fields [Margules et al., 2020]. A study in Bwindi Impenetrable National Park in Uganda has shown that there is a lack of rule adherence in mountain gorilla (Gorilla beringei beringei) tourism [Weber et al., 2020]. This study recommends that visitors should be required to wear facemasks, emphasizing the importance of empowering tour guides and managing visitor expectations. In response to COVID-19, teams at the Tchimpounga Sanctuary and the Gombe Stream research centre in Tanzania have implemented a variety of additional measures and are enforcing IUCN best practice guidelines on great ape health monitoring [Smit, 2020]. The Sabah Wildlife Department in Malaysia has also advised visitors to follow standard operating procedures to reduce the risk of COVID-19 transmission at the Sepilok Orangutan Centre, which reopened to local and Malaysian visitors on June15, 2020 [FMT, 2020]. While the Sumatran Orangutan Conservation Programme (SOCP) has reported taking serious measures to protect the in habitants of their rehabilitation facility [SOCP, 2020] there is scant information from orangutan tourism sites detailing what action is being taken to prepare for reopening of the national parks and thus the protection of the wild orangutan populations.

The seemingly simple way to mitigate the risks illustrated by our study is to have clear rules for visitors to the national park and ensure that these rules are complied with by all stakeholders and strictly enforced by national park authorities. There are clear rules displayed on a large signboard at the official entrance to Gunung Leuser National Park in Bukit Lawang, national park staff have distributed a detailed information leaflet entitled "Wildlife watching and safety information for visitors to Gunung Leuser National Park" to all guest houses and the guide association. A variety of information (available in both English and Bahasa Indonesia) which reflects advice on risk communication has also been produced and distributed [Decker et al., 2012; Muehlenbein, 2017]. Some guest houses and trek providers market their services by focusing on the ethical aspects of trekking, strict rule adherence and actively promote awareness of trekking rules on social media. Despite these efforts both locally and internationally, there appears to be a lack of awareness, limited support for and a worrying lack of interest and apathy from stakeholders in the promotion of such information, which can only serve to benefit the Sumatran orangutan population and have relevance for other orangutan populations, great apes and wildlife viewing sites in general. Lack of visitor awareness about the rules of trekking at Bukit 
Lawang could be explained by poor enforcement, communication distribution of information, and lack of guide education and empowerment. We propose that a major reason for non-compliance is a lack of societal risk response to the disease risk humans present to orangutans, resulting in ignorance about the risk.

\section{CONCLUSION}

Tourism activities in and around Bukit Lawang help to protect the national park, and the park's orangutans are ambassadors for their species [Russon and Russell, 2005; Purwanto, 2016]. However, our study has identified noncompliance with rules by human visitors, which risks exposing the orangutan population in Bukit Lawang to human pathogens, including SARS-CoV-2. It is absolutely crucial that in order to minimize this risk that visitor education is successful. We call upon everyone concerned to help safeguard these Critically Endangered orangutan populations by raising the profile of this information (which could easily be done by sharing information on social media and websites) and promoting awareness so that visitors are aware of their potential impact on the orangutans and can formulate a risk response, such as following the guidelines, before they arrive.

\section{ACKNOWLEDGMENTS}

We gratefully thank the Gunung Leuser National Park authorities in Bukit Lawang for their collaboration with production of guidelines and materials to encourage safe tourism. We also thank local community members in and around Bukit Lawang for their support in distribution and promotion of awareness of the educational materials.

\section{STATEMENT OF ETHICS}

As data were acquired from social media there was no ethical approval required as this research did not involve any handling or disturbance to wildlife. The use of information from social media sites is a popular source for conservation research, and for ethical reasons we analysed only photographs that were shared publicly. All data were anonymized, and no personal information was retained. 


\section{CONFLICT OF INTEREST STATEMENT}

The authors have no conflicts of interest to declare in regard to publication of this paper.

\section{FUNDING SOURCES}

No funding was received in regard to publication of this paper.

\section{AUTHOR CONTRIBUTIONS}

A.M.: conceptualization, data collection, writing, editing; E.H.: writing, editing, validation, visualization; V.N.: conceptualization, methodology, writing, editing; M.K., M.S. and S.C.: writing, editing.

\section{DATA AVAILABILITY STATEMENT}

All data generated or analysed during this study are included in this article. Further enquiries can be directed to the corresponding author.

\section{REFERENCES}

Abrams KM, Leong K, Melena S, Teel T (2020). Encouraging safe wildlife viewing in national parks: effects of a communication campaign on visitors' behaviour. Environmental Communication 14(2): $255-270$.

Ancrenaz M, Sollmann R, Meijaard E, Hearn A J, Ross J, Samejima H, et al. (2014). Coming down from the trees: is terrestrial activity in Bornean orangutans natural or disturbance driven? Scientific Reports 4: 4024.

Arias A (2015). Understanding and managing compliance in the nature conservation context. Journal of Environmental Management 153: 134-43.

Buitendijk H, Fagrouch Z, Niphuis H, Bogers WM, Warren KS, Verschoor EJ (2014). Retrospective serology study of respiratory virus infections in captive great apes. Viruses 6(3): 1442-1453. 
Carrington D (2020). Coronavirus poses lethal threat to great apes experts warn. The Guardian. https://www.theguardian.com/environment/2020/mar/24/coronavirus-poses-lethal-threat-togreat-apes-experts-warn (accessed June 18, 2021).

Corlett RT, Primack RB, Devictor V, et al. (2020). Impacts of the coronavirus pandemic on biodiversity conservation. Biological Conservation 246: 108571.

Decker DJ, Evensen DT, Siemer WF, Leong KM, Riley SJ, Wild MA, et al. (2010). Understanding risk perceptions to enhance communication about human-wildlife interactions and the impacts of zoonotic disease. ILAR journal 51(3): 255-261.

Decker DJ, Siemer WF, Evenson DTN, Stedman RC, McComas KA, Wild MA, et al. (2012). Public perceptions of wildlife-associated disease: risk communication matters. Human-Wildlife Interactions 6(1): 112-122.

Delgado JRA, Van Schaik CP (2000). The behavioural ecology and conservation of the orangutan (Pongo pygmaeus): a tale of two islands. Evolutionary Anthropology 9(5): 201-218.

Dellatore DF, Waitt CD, Foitova I (2009). Two cases of mother-infant cannibalism in orangutans. Primates 50: 277-281.

Dellatore DF, Waitt CD, Foitova I (2014). Impacts of tourism on the behaviour of rehabilitated orangutans (Pongo abelli) in Bukit Lawang, north Sumatra, Indonesia. In Primate Tourism: a Tool for Conservation? (Russon AE, Wallis J eds.), pp 99-120. Cambridge, UK, Cambridge University Press.

Dick M, Rous AM, Nguyen VM, Cooke SJ (2017). Necessary but challenging: Multiple disciplinary approaches to solving conservation problems. FACETS 1: 67-82.

Devaux CA, Mediannikov O, Medkour H, Raoult D (2019). Infectious disease risk across the growing human-non human primate interface: a review of the evidence. Frontiers in Public Health 7: 305.

Dunay E, Apakupakul K, Leard S, Palmer JL, Deem SL (2018). Pathogen transmission from humans to great apes is a growing threat to primate conservation. EcoHealth 15(1): 148-162.

Emery Thompson M, Machanda ZP, Scully EJ, Enigk DK, Otali E, Muller MN, Goldberg TL, Chapman CA, Wrangham RW (2018). Risk factors for respiratory illness in a community of wild chimpanzees (Pan troglodytes schweinfurthii). Royal Society Open Science 5(9): 180840. 
Fairbrass A, Nuno A, Bunnefeld N, et al. (2016). Investigating determinants of compliance with wildlife protection laws: bird persecution in Portugal. European Journal of Wildlife Research 62: 93-101.

FMT (2020). Sabah reopens wildlife park, orangutan and sun bear centres. FMT https://www.freemalaysiatoday.com/category/nation/2020/06/13/sabah-reopens-wildlife-parkorangutan-and-sun-bear-centres/ (accessed June 18, 2021).

Foitová I, Huffman MA, Wisnu N, Olsansky M (2009). Parasites and their impacts on orangutan health. In Orangutans - Geographic Variation in Behavioral Ecology and Conservation (Wich SA, Utami Atmoko SS, Setia TM, Van Schaik CP eds.), pp 157-169. Oxford, UK, Oxford University Press.

Genton C, Cristescu R, Gatti S, Levrero F, Bigot E, Caillaud D, et al. (2012). Recovery potential of a western lowland gorilla population following a major Ebola outbreak: results from a ten year study. PLoS One 7(5): e37106.

Gilardi KV, Gillespie TR, Leendertz FH, Macfie EJ, Travis DA, Whittier CA, et al. (2015). Best practice guidelines for health monitoring and disease control in great ape populations. Gland, Switzerland: IUCN SSC Primate Specialist Group.

Gillespie TR, Leendertz FH (2020). COVID-19: protect great apes during human pandemics. Nature 579: 487.

Glasser DB, Goldberg TL, Guma N, et al. (2021). Opportunities for respiratory disease transmission from people to chimpanzees at an East African tourism site. American Journal of Primatology 83(2): e23228.

Hanisch-Kirkbride SL, Riley SJ, Gore ML (2013). Wildlife disease and risk perception. Journal of Wildlife Diseases 49(4): 841-849.

Hanes AC, Kalema-Zikusoka G, Svensson MS, Hill CM (2018). Assessment of health risks posed by tourists visiting mountain gorillas in Bwindi Impenetrable National Park, Uganda. Primate Conservation 32: 123-132.

IUCN (2020). Great apes, COVID-19 and the SARS CoV-2 - Joint statement of the IUCN Species Survival Commission Wildlife Health Specialist Group and the Primate Specialist Group Section 
on Great Apes. IUCN. https://www.iucn.org/resources/covid-19-resources (accessed June 18, 2021).

Kalter SS, Heberling RL, Cooke AW, et al. (1997). Viral infections of nonhuman primates. Comparative Medicine 47(5): 461-467.

Karokaro AS, Jong HN (2020). For world's rarest great ape, COVID-19 is latest in a litany of threats. Mongabay. https://news.mongabay.com/2020/04/tapanuli-orangutan-covid19-indonesia-sumatraconservation-ape-dam/ (accessed June 18, 2021).

Keane A, Jones JPG, Edwards-Jones G, Milner-Gulland EJ (2008). The sleeping policeman: understanding issues of enforcement and compliance in conservation. Animal Conservation 11: $75-82$.

Kilbourn AM, Karesh WB, Wolfe ND, Bosi EJ, Cook RA, Andau M (2003). Health evaluation of free-ranging and semi-captive orangutans (Pongo pygmaeus pygmaeus) in Sabah, Malaysia. Journal of Wildlife Diseases 39(1): 73-83.

Köndgen S, Kühl Hfoitov, N'Goran PK, Walsh PD, Schenk S, Ernst N, et al. (2008). Pandemic human viruses cause decline of endangered great apes. Current Biology 18(4): 260-264.

Kuze N, Dellatore D, Banes GL, Pratje P, Tajima, T, Russon AE (2012). Factors affecting reproduction in rehabilitant female orangutans: young age at first birth and short inter-birth interval. Primates 53(2): 181-192.

Labes EM, Hegglin D, Grimm F, et al. (2010). Intestinal parasites of endangered orangutans (Pongo pygmaeus) in Central and East Kalimantan, Borneo, Indonesia. Parasitology 137(1): 123-135.

Lappan S, Malaivijitnond S, Radhakrishna S, Riley EP, Ruppert N (2020). The human-primate interface in the New Normal: Challenges and opportunities for primatologists in the COVID-19 era and beyond. American Journal of Primatology 82(8): e23176.

Lenzi C, Speiran S, Grasso C (2020). "Let me take a selfie": reviewing the implications of social media for public perceptions of wild animals. Society and Animals: doi.org/10.1163/15685306BJA10023. 
Lewis S (2020). Coronavirus poses potentially lethal threat to endangered great apes, experts warn. CBS News. https://www.cbsnews.com/news/coronavirus-threat-endangered-species-great-apes/ (accessed June 18, 2021).

Macfie EJ, Williamson EA (2010). Best practice guidelines for great ape tourism. Gland, Switzerland, IUCN/SSC Primate Specialist Group.

Margules C, Boedhihartono AK, Langston JD, Riggs RA, Sari DA, Sarkar S, et al. (2020). Transdisciplinary science for improved conservation outcomes. Environmental Conservation 47(4): 224-233.

Melin AD, Janiak MC, Marrone F, et al. (2020). Comparative ACE2 variation and primate COVID-19 risk. Communications Biology 3: 641.

Montague B (2020). Orangutans existence threatened by coronavirus. The Ecologist. https://theecologist.org/2020/mar/27/orangutans-existence-threatened-coronavirus (accessed June $18,2021)$.

Moorhouse TP, Dahlsjö CAL, Baker SE, D'Cruze NC, Macdonald DW (2015). The customer isn't always right—conservation and animal welfare implications of the increasing demand for wildlife tourism. PLoS One 10(10): e0138939.

Morse SS, Mazet JA, Woolhouse, M, Parrish CR, Carroll D, Karesh WB, et al. (2012). Prediction and prevention of the next pandemic zoonosis. The Lancet 380(9857): 1956-1965.

Muehlenbein MP, Martinez LA, Lemke AA, Ambu L (2008). Perceived vaccination status in ecotourists and risk of anthropozoonoses. Ecohealth 5(3): 371-378.

Muehlenbein MP, Martinez LA, Lemke AA, Ambu L, Nathan S, Alsisto S, Sakong R (2010). Unhealthy travelers present challenges to sustainable primate ecotourism. Travel Medicine and Infectious Disease 8(3): 169-75.

Muehlenbein M, Wallis J (2014). Considering risks of pathogen transmission associated with primatebased tourism. In Primate Tourism: A Tool for Conservation? (Russon A, \& Wallis J, eds.), pp. 278-291. Cambridge, Cambridge University Press.

Muehlenbein MP (2017). Primates on display: Potential disease consequences beyond bushmeat. American Journal of Physical Anthropology 162(S63): 32-43. 
Mul IF, Paembonan W, Singleton I, et al. (2007). Intestinal parasites of free-ranging, semicaptive, and captive Pongo abelii in Sumatra, Indonesia. International Journal of Primatology 28: 407-420.

Mynářová A, Foitová I, Kváč M, Květoňová D, Rost M, Morrogh-Bernard H, Nurcahyo W, Nguyen C, Supriyadi S, Sak B (2016). Prevalence of Cryptosporidium spp., Enterocytozoon bieneusi, Encephalitozoon spp. and Giardia intestinalis in wild, semi-wild and captive oratuangutans (Pongo abelii and Pongo pygmaeus) on Sumatra and Borneo, Indonesia. PLoS One 11(3): $\mathrm{e} 0152771$.

Nekaris KAI, Musing L, Vazquez AG, Donati G (2016). Is Tickling Torture? Assessing Welfare towards Slow Lorises (Nycticebus spp.) within Web 2.0 Videos. Folia Primatologica 86: 534 551.

Nurcahyo W, Konstanzová V, Foitová I (2017). Parasites of orangutans (primates: Ponginae): An overview. American Journal of Primatolology 79: e22650.

Otsuka R, Yamakoshi G (2020). Analyzing the popularity of YouTube videos that violate mountain gorilla tourism regulations. PLoS One 15(5): e0232085.

Patrono LV, Samuni L, Corman VM, Nourifar L, Röthemeier C, Wittig RM, et al. (2018). Human coronavirus OC43 outbreak in wild chimpanzees, Côte d' Ivoire. Emerging Microbes \& Infections 7(1): 1-4.

Philippa J, Dench R (2019). Infectious diseases of orangutans in their home ranges and in zoos. In Fowler's Zoo and Wild Animal Medicine Current Therapy, Volume 9 (Miller RE, Lamberski N, Calle PP, eds.), pp 565-573. Amsterdam, Netherlands, Elsevier.

Purwanto E (2016). An Anti-encroachment Strategy for the Tropical Rainforest Heritage of Sumatra: Towards New Paradigms. Jogyakarta, Indonesia: Tropenbos International Indonesia and UNESCO, xiv $+126 \mathrm{p}$.

Rijksen HD, Meijaard E (1999). Our vanishing relative: the status of wild orang-utans at the close of the twentieth century. Dordrecht, Kluwer Academic Publishers.

Rizzolo JB (2017). Exploring the sociology of wildlife tourism, global risks, and crime. In Conservation Criminology (Gore ML, ed.), pp 133-154. New Jersey, United States, Wiley. 
Russon AE, Erman A, Dennis R (2001). The population and distribution of orangutans (Pongo pygmaeus pygmaeus) in and around the Danau Sentarum Wildlife Reserve, West Kalimantan, Indonesia. Biological Conservation 97(1): 21-28.

Russon AE, Russell CL (2005). Orangutan tourism. In World Atlas of the Great Apes and their Conservation (Caldecott J, Miles L, eds.), pp 264-265. Berkeley, CA: Univ. California Press.

Russon AE, Smith JJ, Adams L (2016). Managing human-orangutan relationships in rehabilitation. In Ethnoprimatology: Primate Conservation in the 21st Century (Waller M, ed.), pp 233-258. Berlin, Springer.

Santos WJ, Guiraldi LM, Lucheis SB (2020). Should we be concerned about COVID-19 with nonhuman primates? American Journal of Primatology 82(8): e23158.

Scully EJ, Basnet S, Wrangham RW, Mullerm MN, Otali E, Hyeroba D, et al. (2018). Lethal respiratory disease associated with human Rhinovirus C in wild chimpanzees, Uganda, 2013. Emerging Infectious Diseases 24(2): 267-274.

Smit H (2020). Reacting to COVID-19: How JGI is responding. The Jane Goodall institute of Canada. https://janegoodall.ca/our-stories/reacting-to-covid-19/ (accessed June 18, 2021).

Smits WTM, Heriyanto, Ramono WS (1995). A new method for rehabilitation of orangutans in Indonesia: A first overview. In The Neglected Ape (Nadler RD, Galdikas BMF, Sheeran LK, Rosen N, eds.), pp 69-77, New York, Plenum Press.

SOCP (2020). Preparing in case of COVID-19 at the SOCP Orangutan Rescue and Rehabilitation Centre. Sumatran Orangutan Conservation Programme. https://www.sumatranorangutan.org/2020/03/media/news/preparing-in-case-of-covid-19-at-thesocp-orangutan-rescue-and-rehabilitation-centre/ (accessed June 18, 2021).

Solomon JN, Gavin MC, Gore ML (2015). Detecting and understanding non-compliance with conservation rules. Biological Conservation 189: 1-4.

Stuart P, Yalcindag E, Ali IKM, Pecková R, Nurcahyo W, Morrogh-Bernard H, Foitová I (2020). Entamoeba histolytica infections in wild and semi-wild orangutans in Sumatra and Kalimantan. American Journal of Primatology 82(5): e23124. 
Susilawati SS, Fauzi A, Kusmana C, Santoso, N (2020). Strategi dan kebijakan dalam pengelolaan wisata konservasi orangutan sumatera (Pongo abelii) di Bukit Lawang Kabupaten Langkat Sumatera Utara. Journal of Natural Resources and Environmental Management 10(1): 1-11.

Thomas-Walters L, McNulty C, Veríssimo D (2020). A scoping review into the impact of animal imagery on pro-environmental outcomes. Ambio 49: 1135-1145.

Toivonen T, Heikinheimo V, Fink C, Hausmann A, Hiippala T, Järv O, et al. (2019). Social media data for conservation science: a methodological overview. Biological Conservation 233: 298315.

UN (2020). Virus which causes covid-19 threatens great ape conservation. United Nations Indonesia. https://www.un.or.id/blog/80-news/275-virus-which-causes-covid-19-threatens-great-apeconservation (accessed September 20, 2020).

UNESCO (2020). Great apes and covid-19, an additional threat to already endangered species? UNESCO. https://en.unesco.org/news/great-apes-and-covid-19-additional-threat-alreadyendangered-species (accessed June 18, 2021).

USDA (2021). Confirmation of COVID-19 in gorillas at a California zoo. https://www.aphis.usda.gov/aphis/newsroom/stakeholder-info/sa_by_date/sa-2021/sa-01/ca- sars-cov-2 (accessed April 10, 2021).

Van der Meer E, Botman S, Eckhardt S (2019). I thought I saw a pussy cat: Portrayal of wild cats in friendly interactions with humans distorts perceptions and encourages interactions with wild cat species. PloS One 14(5): e0215211.

Van Hamme G, Svensson MS, Morcatty TQ, Nekaris KAI, Nijman V (2021). Keep your distance: using Instagram posts to evaluate the risk of zoonotic disease transmission in gorilla ecotourism. People and Nature 3(2): 325-334.

Vyawahare V (2020). National parks in Africa shutter over COVID-19 threat to great apes. Mongabay. https://news.mongabay.com/2020/03/national-parks-in-africa-shutter-over-covid-19threat-to-great-apes/ (accessed June 18, 2021).

Warren KS (2001). Orangutan conservation: epidemiological aspects of health management and population genetics. PhD dissertation, Murdoch Univer $\neg$ sity. 
Weber A, Kalema-Zikusoka G, Stevens NJ (2020). Lack of rule-adherence during mountain gorilla tourism encounters in Bwindi Impenetrable National Park, Uganda, places gorillas at risk from human disease. Frontiers in Public Health 8: 1.

Wells SK, Sargent EL, Andrews ME, Anderson DE (1990). Medical Management of the Orangutan. Louisiana, The Audubon Institute.

Wilkins EJ, Smith JW, Keane R (2020). Social media communication preferences of national park visitors. Applied Environmental Education \& Communication 19(1): 4-18.

Zoo Atlanta (2021). Update On Gorilla Population — Sept 17. https://zooatlanta.org/update-ongorilla-population-sept-17/ (accessed September 30, 2021). 